\title{
Hvad kan en udstilling?
}

af mag.scient. Margrethe Brock-Nannestad

P̊̊ Det kongelige Bibliotek äbner i januar 1993 en udstilling om David Simonsen og den tyske forbindelse Mindretal søger identitet. Udstillingsredaktøren fortxller her om de senesteårs interesse for udstillinger om jødiskeemner og om David Simonsen, hvis store jødiskeforskningsbibliotek Det kongelige Bibliotekerhvervede i 1932 .

"Januar 1993" lyder som et helt harmløst tidspunkt, uden minder om erobringer, opdagelser eller forfølgelser. Derimod er januar 1992 en jubilæumsmåned, 50-året for Wannseekonferencen ${ }^{1)}$, og hele 1992 bærer præg af at være til minde om voldsomme kulturmøder. I den moderne tyske omgang med historien er jubilæer vigtige som støttepunkter for erindringen, til at holde fast i for at kunne mindes. I januar 1992 åbnede i Berlin både et minde/lærested i Wannseekonferencens villa og en udstilling af helt andre dimensioner: Jødiske Verdener ${ }^{2}$ ) arrangeret af Berliner Festspiele. I januar 1993 åbner Det kongelige Bibliotek den første af jubilæumsudstillingerne for 200-året som offentligt bibliotek - om David Simonsen og den tyskjødiske kultur. Det bliver en udstilling som både handler om bibliotekshistorie og tyskjødisk historie, om en enkelt person og om et mindretals identitet.

I Tyskland er der i de seneste 15 år blevet lavet mange udstillinger om tyskjødisk historie, fortrinsvis som lokalhistorie - jøder i Hamburg, i Berlin, i Bayern, I Rhinlandet - og mange museer har små afdelinger, der beskriver de forhenværende jødiske medborgeres liv før 1933 og skæbne derefter. Det store problem for tyske udstillingsproducenter er altid at finde udstillingsgenstande, så alt ikke blot skal præsenteres på plancher, en bog sat op på væggen. Af let forståelige årsager er der i Tyskland ikke 
bevaret ret mange eksempler på jødisk materiel kultur - kunsthåndværk, dagligdags brugsgenstande, kunst, rituelle genstande, bøger - så udstillingsproducenterne må næsten altid låne i udlandet. Det er også sket til udstillingen i Berlin, hvor størstedelen af de 2.500 udstillingsobjekter er lånt fra udenlandske samlinger, inklusive Det kongelige Bibliotek, og det er ikke første gang biblioteket bidrager til store udstillinger om jødisk liv i Tyskland.

Jødiske Verdener skildrer jødisk liv mange andre steder end i Tyskland, og udstillingenlægger vægt på at vise jøder som andet end ofre, som engagerede, skabende, fornyende og kritiserende medlemmer af både mindretallet og flertalssamfundet. Jødehad og antisemitisme har en så diskret plads i udstillingen, at anmeldere har anklaget producenterne for skønmaleri. Udstillingens design er helt traditionelt og dens stærkeste virkemiddel er, at den viser det allerbedste der findes $i$ hele verden af materielle vidnesbyrd om jødiske liv.

Måske er det netop særlig passende at illustrere jødisk kulturhistorie ved hjælp af bøger - 'bogens folk' er jo en gængs betegnelse for det jødiske folk. Udstillingen Jødiske Verdener i Berlin er centreret om ordet og bogen, og den rejser dermed nogle principielle spørgsmål om udvælgelse og præsentation af bøger i en udstilling. Det er frustrerende at se spændende bøger låst inde i montrer, men det er katastrofalt for formidlingen at lade den være afhængig af kedelige bøger, bøger der er reduceret til at være deres egne kartotekskort med forfatter, titel og udgivelsessted som eneste information. I centrum af udstillingen i Berlin vises der utallige bøger fra det 19. og begyndelsen af det 20. århundrede. De fleste af dem repræsenterer den tyskjødiske kulturkreds, som strakte sig ud over det tyske rige til Prag, Wien og Budapest - og mange af dem er kedelige at se på. Sådan behøvede det ikke at være, for de samme bøger, eller bøger der belyser de samme temaer, findes i spændende bind, velbevarede og med fængslende illustrationer. I Judaistisk Afdeling er hele den tyskjødiske kultur repræsenteret, både med bøger der er spændende at se på og med bøger, hvis grånussede udseende uvilkårligt får beskueren til at forestille sig forfatteren og emnet ligeså tørt og trist.

Udstillinger om jødiske emner er forholdsvis sjældne i Danmark, ikke fordi der mangler udstillingsegnet materiale, snarere fordi det er problematisk både for flertallet at præsentere mindretallet og for mindretallet at præsentere sig selv. Hvad skal man lægge vægt på, forskelle eller ligheder, fælles historie eller interne forhold, forfølgelse og redning eller 


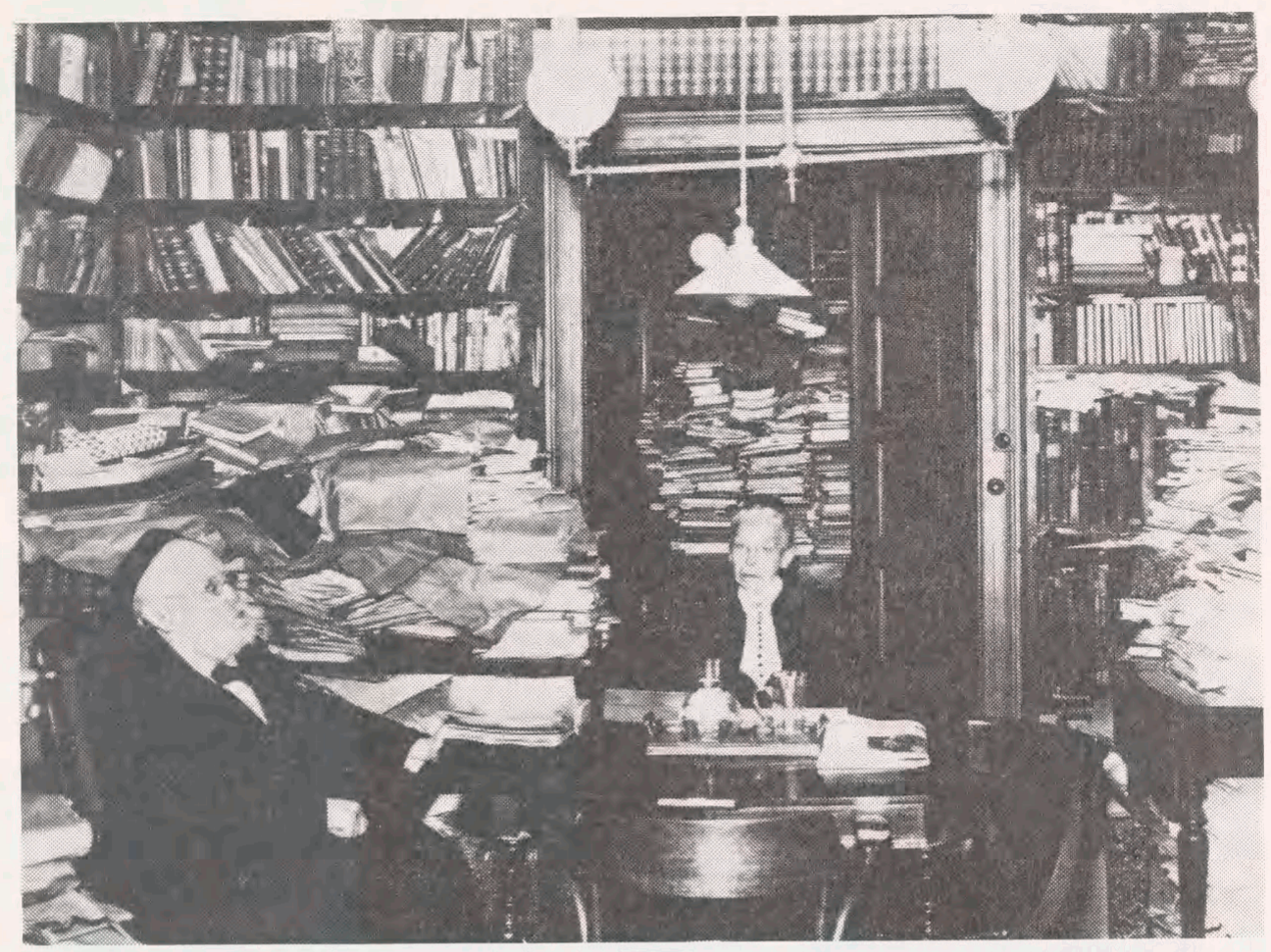

Cora og David Simonsen i hjemmet i Skindergade. Foto fra begyndelsen af 1930erne.

dagliglivets trivialiteter. Det kan være nemmere at lade være med at formidle.

I perioden fra 1880erne til 1933 var problemstillingen om hvordan man som mindretal præsenterer sig for mindretallet og for flertallet særdeles påtrængende for de tyske jøder. I 1871 var de tyske jøder blevet ligeberettigede borgere i det nyskabte tyske kejserrige, og det var en emancipation, som de havde ventet længe på og forberedt sig grundigt til gennem en bevidst og kærlighedsfyldt tilegnelse af tysk sprog og kultur og liberale politiske holdninger.

Opnåelsen af dannelse og aktiv medvirken i flertalssamfundet på alle niveauer var målet for emancipationens tyske jøder. Opnåelsen af virkelig lighed var problematisk i et Tyskland med stærke nationalistiske strømninger, traditionelle religionskampe og nyopfundne raceteorier og antisemitisme. De tyske jøder blev både påvirket af de nationale bevægelser i flertalssamfundet og af den direkte antisemitiske chikane, og identitetsspørgsmålet fik overvældende betydning for dem. Interne diskussio- 


\section{פonographien zur deut(ch)en Rulturge(chichte}

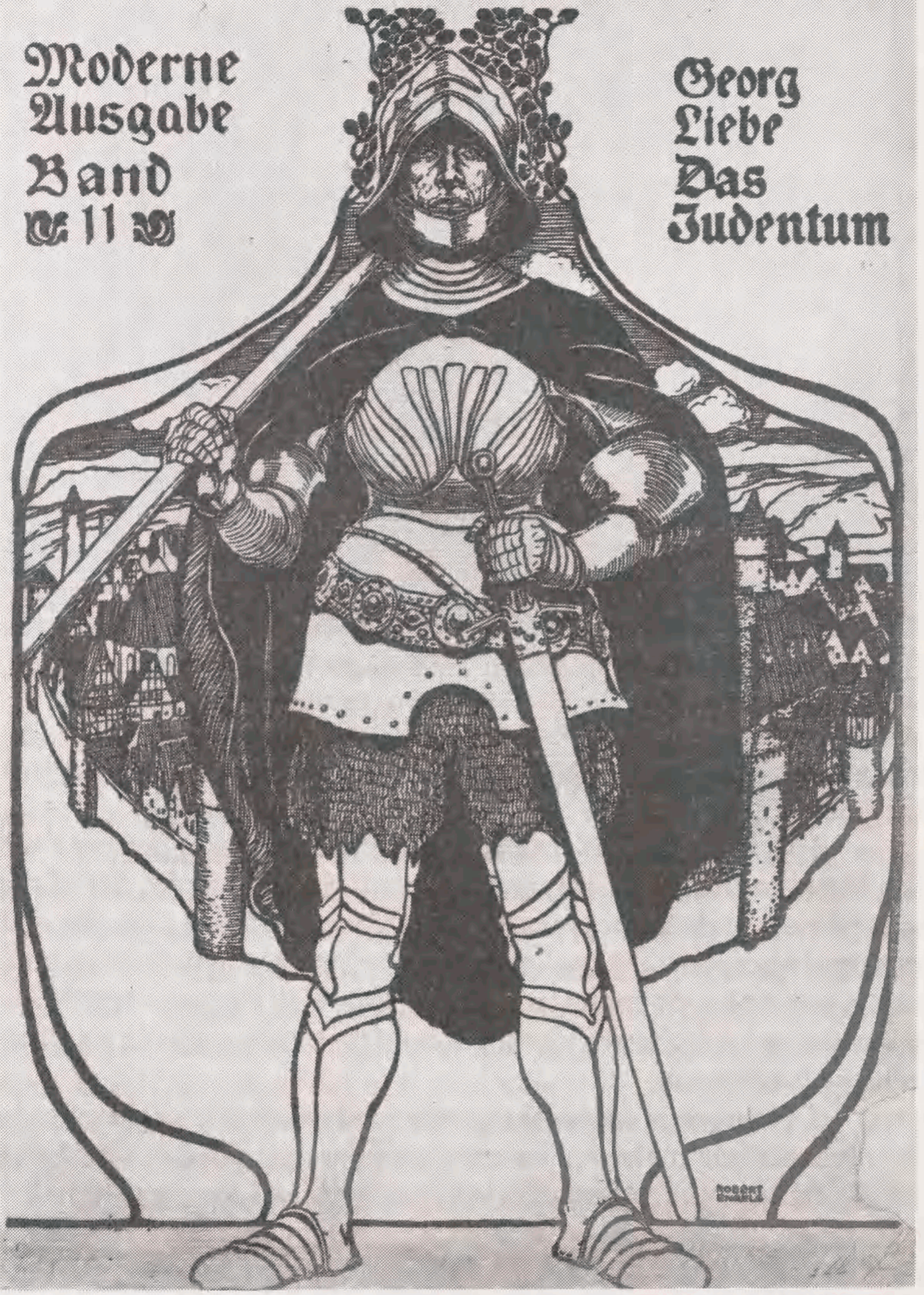

Georg Liebes bog fra 1903 om jødisk historie fik en blandet modtagelse i den jødiske kulturelle presse; i slutningen af $1920 \mathrm{erne}$ blev den genoptrykt som føljeton i familiebladet "Aus alter und neuer Zeit". David Simonsens samling. 
ner om identitet og nationalt tilhørsforhold blev ført i den jødiske presse, gennem publikationer, foredrag, udstillinger og i de mange foreninger, der karakteriserede det jødiske liv i Tyskland. Kunne man overleve som mindretal med egne traditioner, hvis man skulle være ligeværdige borgere? Hvilken betydning havde den jødiske tro i den moderne verden? Var jøder en nation eller snarere tyske borgere af jødisk tro? Forskellige former for jødisk nationalfølelse og nationalisme voksede frem - lige fra den bevidste opfattelseaf det jødiske som noget fortidigt, der skulle bevares på museerne, til den aktive zionisme, der dels skulle genoplive den jødiske kultur og kunst i Europa, dels skulle skabe et hjemland for det jødiske folk i dets gamle land. Det overvældende flertal af de tyske jøder var overbeviste tyske patrioter, der gerne ville have anerkendt den jødiske kultur som en vigtig bidragyder til Europas og Tysklands kultur og historie. Et meget lille mindretal blandt de tyske jøder benægtede at have et særligt forhold til den tyske kultur og accepterede kun det jødiske folk som et værdigt mål for patriotisme. Men begge grupper arbejdede indenfor det tyske og tyskjødiske univers, publicerede og diskuterede på tysk og etablerede institutioner og foreninger, der var direkte paralleller til de tyskeinstitutioner og foreninger, hvor jøder og jødiske emner ikke var velkomne: historie- og litteraturforeninger, sportsklubber, studenterforeninger, museer, universitetslignende forsknings- og undervisningsinstitutioner, lærerseminarier, kvindebevægelser, sangforeninger, spejderbevægelser. Størstedelen af de mange publikationer var beregnet for mindretallet selv, til styrkelse af identiteten, som argumentation for den ene eller anden holdning til fædrelandet og modersproget, som eksperimenter indenfor kunst og litteratur, og til almindelig adspredelse. Man arbejdede bevidst med at skabe nye jødiske udtryksformer inden for bogkunst, og det resulterede i spændende bind og illustrationer, og man lod sig påvirke af de fremherskende æstetiske normer i flertalssamfundet og viste jøder i germansk heltestil.

Det kongelige Bibliotek har en af verdens bedste samlinger af publikationer fra det tyskjødiske univers i perioden fra 1880erne til 1933. Denne mængde af bøger udgør en del af Bibliotheca Simonseniana - det vil sige overrabbiner, professor David Simonsens (1853-1932) private forskningsbibliotek, som Det kongelige Bibliotek erhvervede ved David Simonsens død i 1932. Samlingen var exceptionel, allerede mens Simonsen levede - den kunne i kvalitet og kvantitet måle sig med statsbibliotekets i Frankfurt am Main. Efter Anden Verdenskrigs ødelæggelser af kulturværdier er samlingen 
blevet enestående. David Simonsen var også både exceptionel og enestående for danske forhold. Han rejste efter sin uddannelse som orientalist ved Københavns Universitet til Jüdisch-Theologisches Seminar i Breslau et af hovedcentrene for den forskningsaktivitet, der startede i 1820erne under betegnelsen Wissenschaft des Judentums. Her fik han den tyske rabbineruddannelse, som kombinerede religiøs lærdom med videnskabelig træning og forskning. Hvad der måske var væsentligere, var de mange kontakter til tidens førende forskere indenfor jødiske emner, som han knyttede i Breslau. Selv om David Simonsen valgte at bo og arbejde i København, først som overrabbiner og senere som fri forsker, var hans forskningsunivers i Tyskland. På fotografier fra kurstederne, i hans korrespondance (Simonsens enorme arkiv befinder sig også på Det kongelige Bibliotek), i dedikationer i bøgerne og i bestyrelser for berømte jødiske institutioner bevidnes den høje anseelse, David Simonsen nød: Han rangerede på niveau med Albert Einstein, Sigmund Freud og Chaim Nachman Bialik. Simonsens bogsamling var et brugsbibliotek, som han var nødt til at opbygge, fordi han valgte at bo i København - han kunne hverken findeden ældre eller den nyeste litteratur i andre biblioteker i byen. David Simonsen havde tilsyneladende ingen fordomme over for hverken de tyskpatriotiske tyske jøder eller over for zionisterne; publikationer fra begge grupper er ligeligt repræsenteret $\mathrm{i}$ hans samling.

Udstillingen om David Simonsen og den tyskjødiske kultur, som åbner på Det kongelige Bibliotek i januar 1993, har to sammenhængende formål. Den skal dels præsentere den rigdom af jødisk forskning og kulturel formidling, som fandtes i Tyskland i det trekvarte århundrede før nazisternes magtovertagelse. Den skal også vise David Simonsens betydning for forbindelsen mellem dansk og tysk jødedom og forskning. Det vil ske gennem at udstille bøger, som har været i David Simonsens bibliotekog ved at vise et lille udsnit af hans enorme arkivmateriale, som belyser en exceptionel rabbiner og forskers daglige arbejde for menigheden, for forskningen, for de jødiske indvandrere fra Østeuropa, for genudgivelsen af middelalderlige hebraiske værker. David Simonsens betydning i dag er indlysende - hans samling gør København til et oplagt centrum for forskning i tyskjødisk kulturhistorie.

I udstillingen vil der med et par nødvendige undtagelser kun blive vist bøger, som har været gennem David Simonsens hænder,og som hidrører fra det tyskjødiske univers - det vil sige det tyske kejserrige og Weimarrepublikken, men også i begrænset omfang Wien og Prag. Og så vil der selvfølgelig foregå en vis form for historieforfalskning ved udvælgel- 
sen af materialet: der vil kun blive vist bøger med spændende bind eller illustrationer og ikke et eneste lille grånusset bind, selv om det kommer til at betyde, at meget centrale værker ikke vil blive udstillet. Det kan selvfølgelig give beskueren den opfattelse, at de tyske jøder var omgivet af flere smukke bøger end medlemmer af flertalssamfundet, at der blev ofret mere på den æstetiske præsentation af den egne kultur, og det er næppe rigtigt. Men at vise et repræsentativt udsnit af den tyske del af Simonsens samling - og det vil i praksis sige et repræsentativt snit af tyskjødiske udgivelser fra 1880erne til 1933 - vil kun medføre, at montrene bliver kedelige at se på, og det vil næppe øge forståelsen for den tyskjødiske kultur. Som tekster til udstillingsobjekterne vil der i mange tilfælde blive brugt omtaler, boganmeldelser, debatindlæg eller annoncer fra samtidige tyskjødiske publikationer, det vil sige, at det udstillede materiale kommenterer sig selv.

De tyske jøder er nok det mindretal i historien, der har beskæftiget sig mest med det at væremindretal i et flertalssamfund, med identitetsproblematikken, med spørgsmålet om loyalitet til fædrelandet og definitionen af fædrelandet, og de tyske jøder eksperimenterede med stort set alle former for eksistens: som totalt assimilerede med valg af flertallets religiøse tilhørsforhold, eller som ortodokse jøder med varierende grader af åbenhed overfor flertallets kultur; som tyske borgere af jødisk tro med en traditionel tysk uddannelse, et godt borgerligt erhverv og et aktivt foreningsliv i jødiske rammer, eller som idealistiske socialister; som passive zionister, der interesserede sig for jødisk kunst og støttede oprettelsen af et hjemland for de undertrykte jøder i Østeruropa, eller som aktive zionister, der udvandrede til Palæstina efter en tids træning på en tyskjødisk landbrugsskole.

Udstillingen om David Simonsen og den tyskjødiske kultur kan kun vise glimt af hvad de tyske jøder formåede at producere af forskning og formidling. Men der er ingen grænser for den konkrete viden og inspiration, som man i dag kan hente i de tyske jøders omgang med deres egen historie og placering i flertalssamfundet.

Noter

1. Wannsee-Konferenz 20/1/1942: planlægning og systematisering af udryddelsen af Europas jøder.

2. Udstillingen hedder "Jüdische Lebenswelten. Jüdisches Denken und Glauben, Leben und Arbeiten in den Kulturen der Welt". Berliner Festspiele, Martin-Gropius-Bau 12/1/1992 - 26/4/92. 